\title{
Growth of Juvenile Pollock (Pollachius virens L.) along the Atlantic Coast of Canada with Inferences of Inshore-offshore Movements
}

\author{
D. Clay \\ Marine Fish Division, Department of Fisheries and Oceans, Gulf Fisheries Center, \\ P. O. Box 5030, Moncton, New Brunswick, Canada E1C $9 B 6$ \\ and \\ W. T. Stobo, B. Beck, and P. C. F. Hurley \\ Marine Fish Division, Department of Fisheries and Oceans, \\ Bedford Institute of Oceanography, P. O. Box 1006, Dartmouth, Nova Scotia, Canada B2Y 4A2
}

\begin{abstract}
Data collected from tagging studies along the coast of Nova Scotia and offshore ichthyoplankton surveys were used to investigate growth and inshore-offshore migrations of juvenile pollock.

Age zero pollock from 0.3 to $4.2 \mathrm{~cm}$ in length were found in the offshore plankton between November and June and small pollock at lengths of $7-11 \mathrm{~cm}$ were caught inshore in July. These small pollock appear to have moved inshore after leaving the offshore pelagic community at 3-6 months of age. They remain inshore until they reach approximately $30+\mathrm{cm}$ during their second year. Tagged inshore pollock were observed to grow $17-18 \mathrm{~cm}$ during their first year of life, an annual instantaneous growth rate $(G)$ of 4.1 , and $27-30 \mathrm{~cm}$ by the end of their second year $(G=1.8)$. Seasonal variability in growth was also observed in juvenile pollock. Mean absolute growth from May until August was $1.75 \mathrm{~cm}$ per month, from August until October $1.50 \mathrm{~cm}$ per month, and from November until April about $0.5 \mathrm{~cm}$ per month.
\end{abstract}

A tagging related mortality experiment using winter tagged juveniles indicated a $11 \%$ mortality during the first 3 months after tagging.

\section{Introduction}

Pollock (Pollachius virens, L.) have increased in commercial importance during the last decade, however, much of the biology of this species remains unclear. Current stock assessments (McGlade et al., MS 1984) and commercial fisheries managers (Anon. 1976, 1984) have treated pollock in the Northwest Atlantic as a single stock encompassing the Scotian Shelf, Georges Bank, and the Gulf of Maine. Until recently, fisheries managers in the USA and Canada accepted the hypothesis that these fish move to Massachusetts Bay and Jeffrey's Ledge in the Gulf of Maine (Fig. 1) to spawn in late autumn and early winter. It was thought that they then dispersed throughout the Gulf of Maine and Scotian Shelf during summer. However, as early as 1963, it had been speculated that spawning also occurred on the Scotian Shelf (Steele, 1963). More recently the Scotian Shelf Ichthyoplankton Program (SSIP) of the Canadian Department of Fisheries and Oceans, has confirmed the presence of pollock eggs and larvae on the Scotian Shelf (O'Boyle et al., 1984), and Scott (1980) found larvae in the Bay of Fundy.
This tagging program was established to investigate seasonal movements and distribution of pollock on the Scotian Shelf and, where possible, to study growth of tagged individuals. Initial attempts to tag adult pollock from offshore areas using fish collected from bottom trawls deployed from research vessels proved unsuccessful. Consequently, large numbers of 0-group, 1-year old, and more limited numbers of 2year-old fish that were available from inshore waters were marked. In addition, to investigate possible effects of tag induced mortality, survival of winter tagged juveniles was evaluated by holding pollock in cages. Although tagging was conducted in all seasons, time constraints allowed only one tagging survival study and winter was chosen as a possible worst case scenario.

This paper deals with the aspect of individual fish growth derived from the inshore tagging program. Modal lengths and length ranges of larval and recently metamorphosed fish from offshore SSIP surveys are presently only to establish minimum length of 0-group fish at mid-summer. 


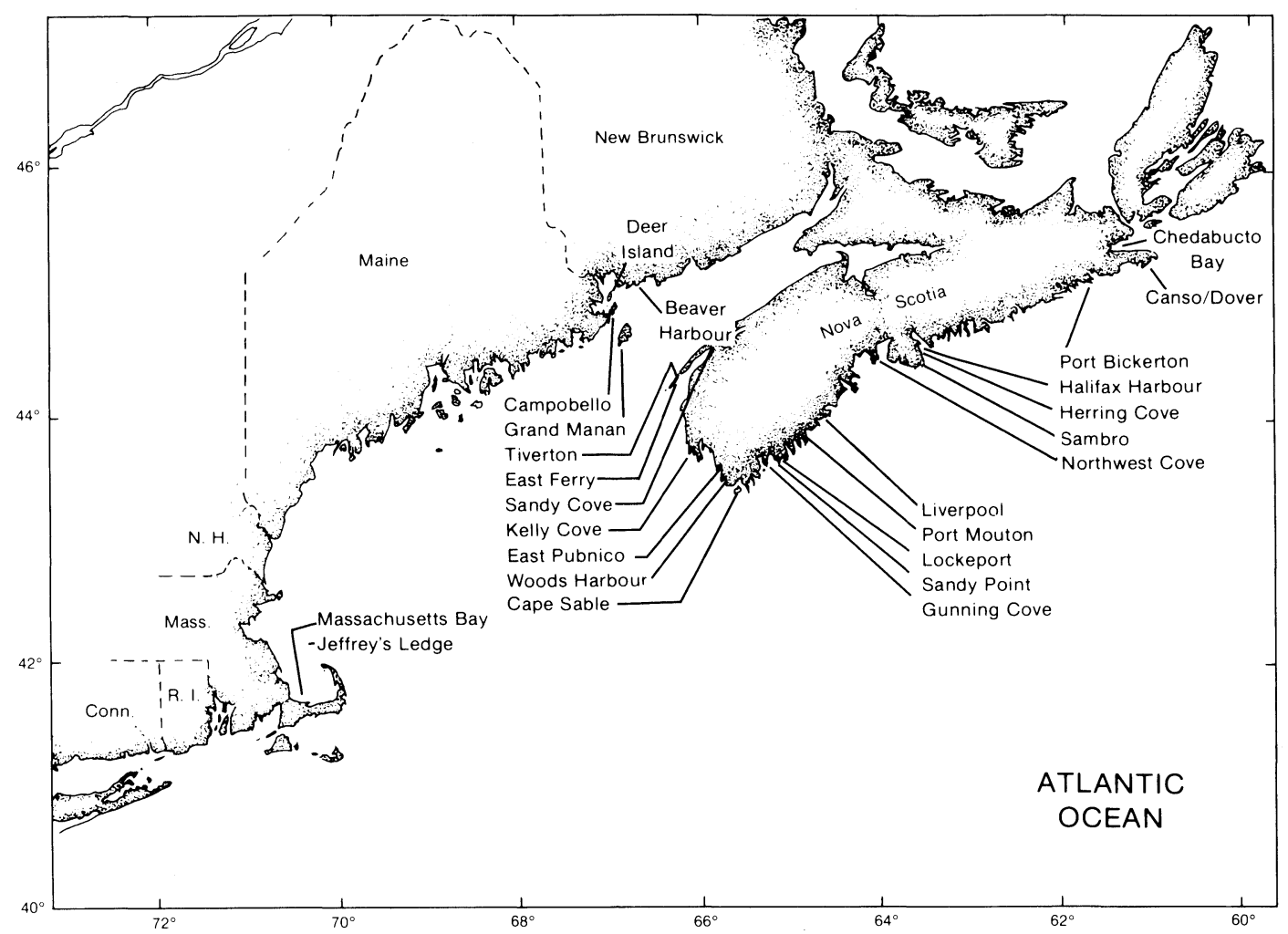

Fig. 1. Map showing the Massachusett's Bay and Jeffrey's Ledge areas and pollock tagging sites along the Atlantic coast of Nova Scotia and New Brunswick between 1978 and 1984. (See Table 1 for tagging dates and numbers of fish tagged.)

\section{Materials and Methods}

Between 1978 and 1984, a large scale pollock tagging study was conducted (see Fig. 1 for sites). All tagging was done using a dart tag with nylon $T$ anchor tags (made by Floy Manufacturing, Seattle, Washington, USA) in the dorsal region, posterior to the first dorsal fin.

During 1979, tagged fish were measured for fork length to the nearest $0.5 \mathrm{~cm}$. In other years all fish or a random sub-sample of fish captured were measured to the nearest $\mathrm{cm}$. Length frequency data were collected from all tagged fish and measurements from a limited number of recaptures were made during tagging operations in 1979 and 1980. In addition, independent of tagging, seasonal length frequencies of inshore pollock were collected. Length frequency samples of small fish $(7-13 \mathrm{~cm})$ were also collected from four areas by scuba divers using small seine nets between mid-July and mid-August, 1982 (D. Beanlands, BIO, pers. comm.).

Although the tagged pollock ranged from 9 to 49 $\mathrm{cm}$ (Table 1), most were less than $20 \mathrm{~cm}$ and were usually not present until mid-summer. They were normally found in large concentrations near fish plant outfalls and caught by angling, dip netting, seining or trap nets. Two major sites of tagging for juveniles (ages 0 and 1) were Halifax Harbour and Tiverton, Nova Scotia.
Absolute growth in length of recaptured fish was calculated as a weighted mean of the change in length, divided by the time-at-large in months:

$$
\frac{L_{2}-L_{1}}{t}
$$$$
\text { Absolute growth in length }
$$

where $L_{1}$ and $L_{2}$ are the fork lengths $(\mathrm{cm})$ at the beginning and the end of the period respectively, and $t$ is the time period (months) at large. Growth in length is described as the mean \pm 1 standard deviation.

Instantaneous growth rates (G) for either monthly or annual periods have been calculated from lengths as described by Ricker (1975) using the formula:

$$
\mathrm{G}=\mathrm{b}\left(\ln \mathrm{L}_{2}-\ln \mathrm{L}_{1}\right)
$$

where $L_{1}$ and $L_{2}$ are the lengths at the beginning and end of the period respectively and $b$ is the slope of the logarithmic transformation of the length weight regression. The ' $b$ ' value was obtained from the length weight relationship calculated for pollock taken from the same areas and of a similar size range, this relationship for fish between 10 and $40 \mathrm{~cm}$ was:

$$
W=0.00885 \times F L^{3.11483}, n=198, r^{2}=0.99
$$

where $W$ is the weight $(\mathrm{g})$ and $F L$ is the fork length $(\mathrm{cm})$ (Fig. 2). Deriving the length weight relationship from these fish was necessary as the tagged fish were not 
TABLE 1. Locations, dates, and associated data for selected pollock tagging trips along the coasts of Nova Scotia (N.S.) and New Brunswick (N.B.) between 1978 and 1984

\begin{tabular}{|c|c|c|c|c|}
\hline Year & Location & Date & $\begin{array}{l}\text { Pollock } \\
\text { tagged }\end{array}$ & $\begin{array}{l}\text { Length range } \\
\qquad(\mathrm{cm})\end{array}$ \\
\hline 1978 & Canso/Dover, N.S. & 22-23 Jun & 991 & $23-43$ \\
\hline \multirow[t]{13}{*}{1979} & Canso/Dover, N.S. & 1-6 Jun & 5,670 & $20-49$ \\
\hline & Liverpool, N.S. & 26 Jun & 22 & $22-37$ \\
\hline & Sandy Cove, N.S. & 8-14 Jun & 39 & $35-42$ \\
\hline & Tiverton, N.S. & 9-13 Jul & 2,313 & $22-31$ \\
\hline & Tiverton, N.S. & 21-23 Aug & 657 & $22-36$ \\
\hline & Halifax, N.S. & 22-25 Aug & 297 & $10-40$ \\
\hline & Tiverton, N.S. & 9 Oct & 300 & $15-39$ \\
\hline & Gunning Cove, N.S. & $29 \mathrm{Oct}$ & 151 & $12-24$ \\
\hline & Tiverton, N.S. & $30 \mathrm{Oct}$ & 48 & $15-39$ \\
\hline & Halifax, N.S. & 5-6 Nov & 2,112 & $13-45$ \\
\hline & Lockeport, N.S. & $7 \mathrm{Dec}$ & 66 & $13-22$ \\
\hline & Gunning Cove, N.S. & $7 \mathrm{Dec}$ & 45 & $13-22$ \\
\hline & Tiverton, N.S. & $8 \mathrm{Dec}$ & 36 & $15-19$ \\
\hline \multirow[t]{18}{*}{1980} & Halifax, N.S. & 4 Jan & 98 & $15-23$ \\
\hline & Tiverton, N.S. & $10 \mathrm{Jan}$ & 200 & $13-19$ \\
\hline & Halifax, N.S. & 4-6 Feb & 97 & $15-21$ \\
\hline & Herring Cove, N.S. & Feb-Mar & 202 & $14-21$ \\
\hline & Halifax, N.S. & $3 \mathrm{Apr}$ & 40 & $15-24$ \\
\hline & Halifax, N.S. & 13 May & 1,632 & $15-29$ \\
\hline & Canso/Dover, N.S. & 14-16 May & 3,000 & $20-37$ \\
\hline & Northwest Cove, N.S. & $7-9 \mathrm{Jul}$ & 53 & $20-24$ \\
\hline & Sambro, N.S. & $15 \mathrm{Jul}$ & 12 & $9-20$ \\
\hline & East Ferry, N.S. & $17 \mathrm{Jul}$ & 91 & $9-11$ \\
\hline & Tiverton, N.S. & $17 \mathrm{Jul}$ & 600 & $9-45$ \\
\hline & Halifax, N.S. & 29-30 Jul & 484 & $11-25$ \\
\hline & South Shore, N.S. ${ }^{a}$ & 4-8 Aug & 186 & $12-35$ \\
\hline & Tiverton, N.S. & 10 Sep & 596 & $16-44$ \\
\hline & East Ferry, N.S. & $10 \mathrm{Sep}$ & 901 & $12-18$ \\
\hline & Cape Sable, N.S. & $10 \mathrm{Nov}$ & 1,496 & $13-19$ \\
\hline & Cape Sable, N.S. & $28 \mathrm{Nov}$ & 1,000 & $14-20$ \\
\hline & Beaver Harbour, N.B. & 18-19 Dec & 1,996 & $12-17$ \\
\hline \multirow[t]{4}{*}{1981} & Canso/Dover, N.S. & 21-26 May & 3,013 & $20-35$ \\
\hline & Tiverton, N.S. & 22 Aug & 300 & $23-26$ \\
\hline & Beaver Harbour, N.B. & 7 Oct & 800 & $13-22$ \\
\hline & Cape Sable, N.S. & $22-28$ Oct & 3.919 & $14-33$ \\
\hline \multirow[t]{2}{*}{1982} & Campobello, N.B. & 20-21 May & 3,999 & $16-28$ \\
\hline & Canso/Dover, N.S. & 20-26 May & 3,993 & $20-44$ \\
\hline \multirow[t]{6}{*}{1983} & Deer Island, N.B. & 30 May & 800 & $12-23$ \\
\hline & Canso/Dover, N.S. & 27-31 May & 5,131 & $20-29$ \\
\hline & & $1-5$ Jun & & $20-47$ \\
\hline & Campobello, N.B. & 31 May & 700 & $18-25$ \\
\hline & Campobello, N.B. & 1 Jun & 1,497 & $17-26$ \\
\hline & Grand Manan, N.B. & 3 Jun & 1,927 & $17-25$ \\
\hline \multirow[t]{2}{*}{1984} & Grand Manan, N.B. & 5-7 Jun & 3,998 & $16-36$ \\
\hline & Total & $1978-84$ & 56,408 & \\
\hline
\end{tabular}

a Tagging along the South Shore was conducted at East Pubnico, Kelly Cove Cape Sable, Lockeport, and Woods Harbour.

weighed in order to keep handling to a minimum. Fish sampled from the ichthyoplankton surveys had no weight data collected and thus the scaling factor (for Ricker's 1975 equation) was set to 3.0 .

The SSIP surveys, which ran concurrently with the present work, were designed to provide distribution and abundance indices (O'Boyle et al., 1984). They were not designed to provide a larval fish age and growth data series, consequently the preservation techniques precluded the study of the larval otoliths for daily growth. All fish from the samples were removed

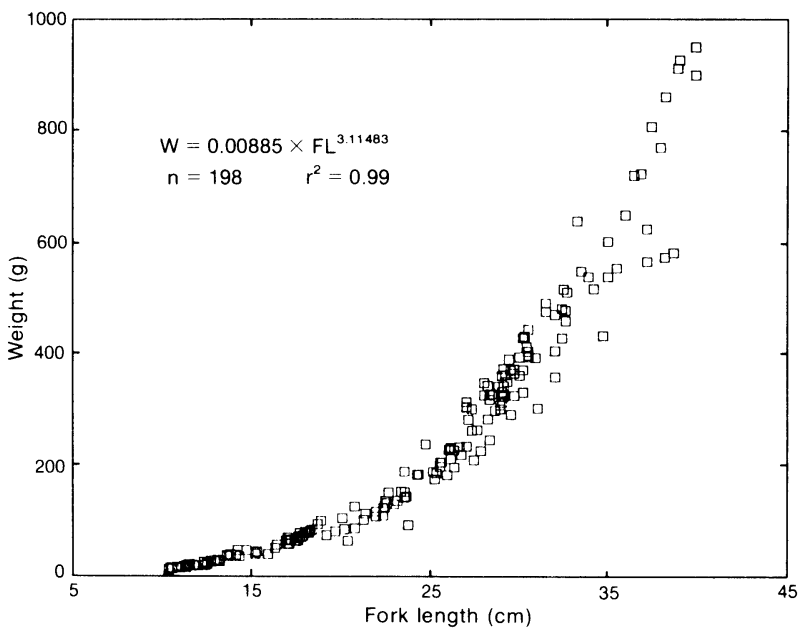

Fig. 2. Length weight relationship of juvenile pollock (10 to $40 \mathrm{~cm}$ ) from the east coast of Canada during 1979 and 1980.

from the gear, preserved, and later identified, counted and the larvae measured for length to the nearest $\mathrm{mm}$. Length was measured as notochord length until the posterior edge of the hypural plate was observed to be vertical, then standard length was used. No data were available on the expected shrinkage after the preservation, however, we feel that this shrinkage would not be significant for the present use of the data. The length data from these surveys were used solely to establish that fish caught inshore in mid-summer were of the year-class produced in the preceding winter.

A study to assess possible large scale bias due to differential mortality that might result from tagging in different seasons was carried out using 150 pollock captured in a research cod trap in Halifax Harbour in December 1979. The depth at the capture site was 8-10 $\mathrm{m}$. The fish were transported in 85 liter tanks from the harbour to a holding cage $\left(30 \mathrm{~m}^{3}\right)$ moored in the Bedford Basin at the Bedford Institute of Oceanography (BIO). They were acclimated in the holding cage for 16 days prior to tagging. Every 3 to 4 days throughout the study and acclimation period they were fed chopped cod and herring. In January 1980, 102 of the surviving 145 fish were tagged, and the rest left as controls; all were measured to the nearest $\mathrm{mm}$ fork length then and in subsequent experiments. The cage was inspected weekly for fish mortality and signs of abnormal swimming and feeding activity. In March when the cage was replaced because of algal fouling, the fish were examined and measured. The fish were released at the holding site at the end of May after counting but without being measured.

\section{Results and Discussion}

\section{Growth estimated from ichthyoplankton surveys}

Fahay (1983) reported the size at hatching on Georges Bank as 0.3 to $0.4 \mathrm{~cm}$ in length with the young 
settling to the bottom by the time they had reached 5 $\mathrm{cm}$. The SSIP survey data (Fig. 3) confirm that pollock spawn over the Scotian Shelf, as previously suggested by Steele (1963). The data suggest that pollock appear to spawn on the Scotian Shelf (offshore) between November and March with peak spawning occurring between December and February as reported by O'Boyle et al., 1984. A similar temporal pattern has been observed on Georges Bank (Colton and Byron, 1977; Colton et al., 1979). For this reason we have arbitrarily assigned 1 January as the birthdate of Scotian Shelf pollock in this growth study.

It is probable that larval pollock migrate inshore as they grow, entering bays and estuaries where small fish are commonly found. This was suggested by Steele (1963) for small pollock over 3-cm long in European waters. Such a movement has also been noted by Scott (1980) for pollock juveniles in the Bay of Fundy. Steele's (1963) observation that they remain inshore for their first 2 years of life is supported by the fact that no small pollock have been caught over the Scotian Shelf during any of the juvenile surveys that have been conducted annually since 1978 using small mesh bottom trawl.

Although we have no direct evidence at this time, our ichthyoplankton data suggest that larval pollock concentrate inshore as they grow and their decline in abundance in the SSIP samples suggest that they disappear from the offshore plankton by July. This is coincident with the inshore appearance of small pollock, although at a larger size than that reported from Europe (Steele, 1963). The question whether this inshore movement is a passive drift or an active migration remains to be answered.

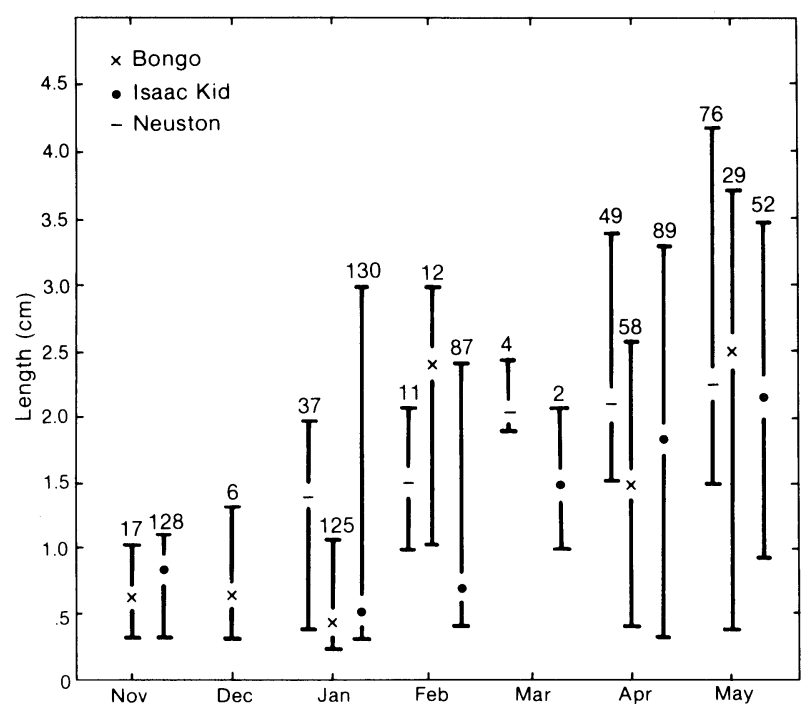

Fig. 3. Length of pollock collected from three plankton gears fished over the Scotian Shelf during 1979 and 1980 . The bars represent the range of lengths, the numbers over the bars are the sample size, and the gear symbol is located at the median length.
While the preservation method of samples precluded the use of otoliths to identify young of the year pollock, the authors are also not aware of any publication on age validation work on pollock from the east coast of North America.

Due to high variability in sample numbers and length ranges of fish caught in the three gears, data from all gear types are presented to provide a composite view (Fig. 3). The data indicate larvae appear in the offshore water column in November at lengths of 0.3 to $1.1 \mathrm{~cm}$ and by May, the larvae are observed at lengths of 0.4 to $4.2 \mathrm{~cm}$. The continued presence of small pollock in the samples throughout the November to May period indicates a protracted spawning period; the increasing trend in maximum and median lengths provide a minimum estimate of growth of an earlier stage of the year-class.

Size dependent gear avoidance by larval and post larval fish is well documented (Clutter and Anraku, 1968), therefore the maximum lengths taken by these gears would underestimate the upper limits of growth. This underestimate may also be influenced by the change in behaviour from a pelagic to demersal existence (Fahay, 1983). To provide a first estimate of $G$ for the larval and post larval planktonic stages of pollock, the change in the median lengths of fish caught in the neuston net are assumed to be representative of their growth; in this case $\mathrm{G}$ is approximately 0.4 .

\section{Growth - inshore phase}

Many bays along the coast of Nova Scotia have at least one fish processing plant, and all of these discharge some form of fish protein back into the ocean. We observed that during the summer, young pollock, frequently in the order of several thousands of fish, form dense feeding concentrations near these discharge pipes. Field observations of gut contents of some of these fish indicate flesh and skin fragments from larger fish predominate their diets. No quantitative data were collected.

The fish were observed to remain in the vicinity of the outfalls at least until the following January. Although no temperature preference studies were conducted, the pollock were observed to leave the area when the water temperature dropped below $4^{\circ} \mathrm{C}$, during the January to April period, when these pollock were 16-24 cm in length (Fig. 4). On calm, sunny days they often reappeared inshore, and resumed active feeding. From this we conclude that they departed to adjacent deep water, where temperatures were more stable. Sequential observations near the effluent outfalls showed they were present at the beginning of May. Around mid-July a new cohort $(7-11 \mathrm{~cm})$ arrived and from July to November both groups utilized the area. By November, many of the second year fish which were in excess of $30 \mathrm{~cm}$ in length left the area, presumably moving into deeper offshore water. The new cohort 


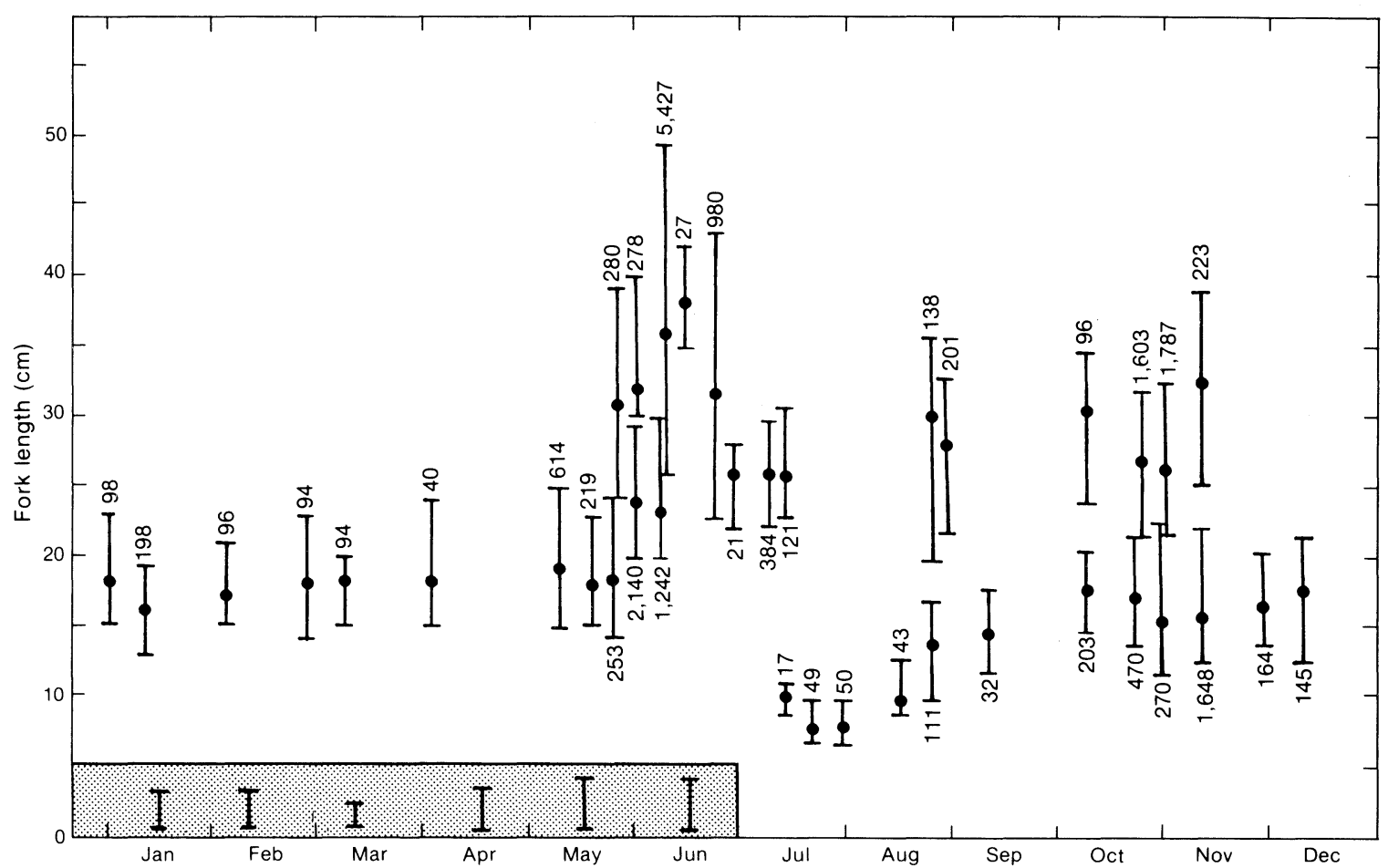

Fig. 4. Median and range of lengths of pollock sampled at various tagging sites over several years (see Table 1). All years combined to produce an 'annual view'. The shaded area represents ichthyoplankton data (see Fig. 2), the remainder of the data come from this tagging study. The bars represent the range of lengths, the numbers at one of the bars are the sample size, and the dot is the median length.

continues to grow and replace the second year fish and carry on in the localized apparently temperature related movement.

The size range of the inshore pollock studied was $7-40+\mathrm{cm}$ (Fig. 4). During the July to November period, there were two discrete length groups in this population component indicating two distinct cohorts. A third cohort of larger fish may be present for a short period in spring, mid-May to mid-June. The smaller-sized cohort did not increase greatly in median length between October and April. The average length of the cohort of smaller fish during this winter period, at the end of their first year, was $17-18 \mathrm{~cm}$; for the cohort of larger fish, at the end of their second year, the average length was $27-30 \mathrm{~cm}$.

During 1978, 97 previously tagged fish were recaptured at their release site. These were measured for length and released a second time. These data also indicate two distinct cohorts inhabiting the inshore area (Fig. 5). Pollock of the larger and smaller cohorts from Halifax, exhibited a weighted mean growth of $1.38 \pm 0.48(n=8)$ and $1.42 \pm 0.55(n=10) \mathrm{cm}$ per month respectively from August to early November. The values of $\mathrm{G}$ for this time period were approximately 0.05 and 1.10 respectively. Between November and May the cohort of smaller fish, with an initial median size of $17-18 \mathrm{~cm}$, grew about $0.52 \pm 0.24(n=36) \mathrm{cm}$ per month $(G=0.04)$, then showed increased growth that about
$2.23 \pm 0.59(n=6) \mathrm{cm}$ per month $(\mathrm{G}=0.15)$ between May and July. Growth of a single cohort in adjacent years (Fig. 5), suggests that juveniles grow approximately $1.75 \mathrm{~cm}$ per month during May to November and about $0.5 \mathrm{~cm}$ per month during the rest of the year. The November to May length data suggest that little growth occurs during the winter months.

The cage data indicates an even lower growth rate of $0.12 \mathrm{~cm}$ per month in the January to March period. This difference, however, is possibly due to a combination of the experimental conditions and the timing of the cage experiment in mid-winter.

Pollock from Tiverton (Fig. 5) exhibited a weighted mean growth of $1.75(n=16) \mathrm{cm}$ per month $(\mathrm{G}=0.19)$ between July and October, and a lower weighted mean growth of $0.59(n=9) \mathrm{cm}$ per month $(\mathrm{G}=0.04)$ between October and December. The generally similar growth patterns at Halifax and Tiverton suggest a summer rate (May through August) of approximately $1.75 \mathrm{~cm}$ per month, a subsequent decline during autumn (August to October/November) to about $1.5 \mathrm{~cm}$ per month, and a winter rate (November through April) of approximately $0.5 \mathrm{~cm}$ per month. With the strong seasonal temperature cycle found in Atlantic Canada and its likely effect on pollock growth, we would expect that the actual pattern of annual growth should be curvilinear rather than linear as suggested in Fig. 5. Although the nature of the data makes it difficult to consider growth other 


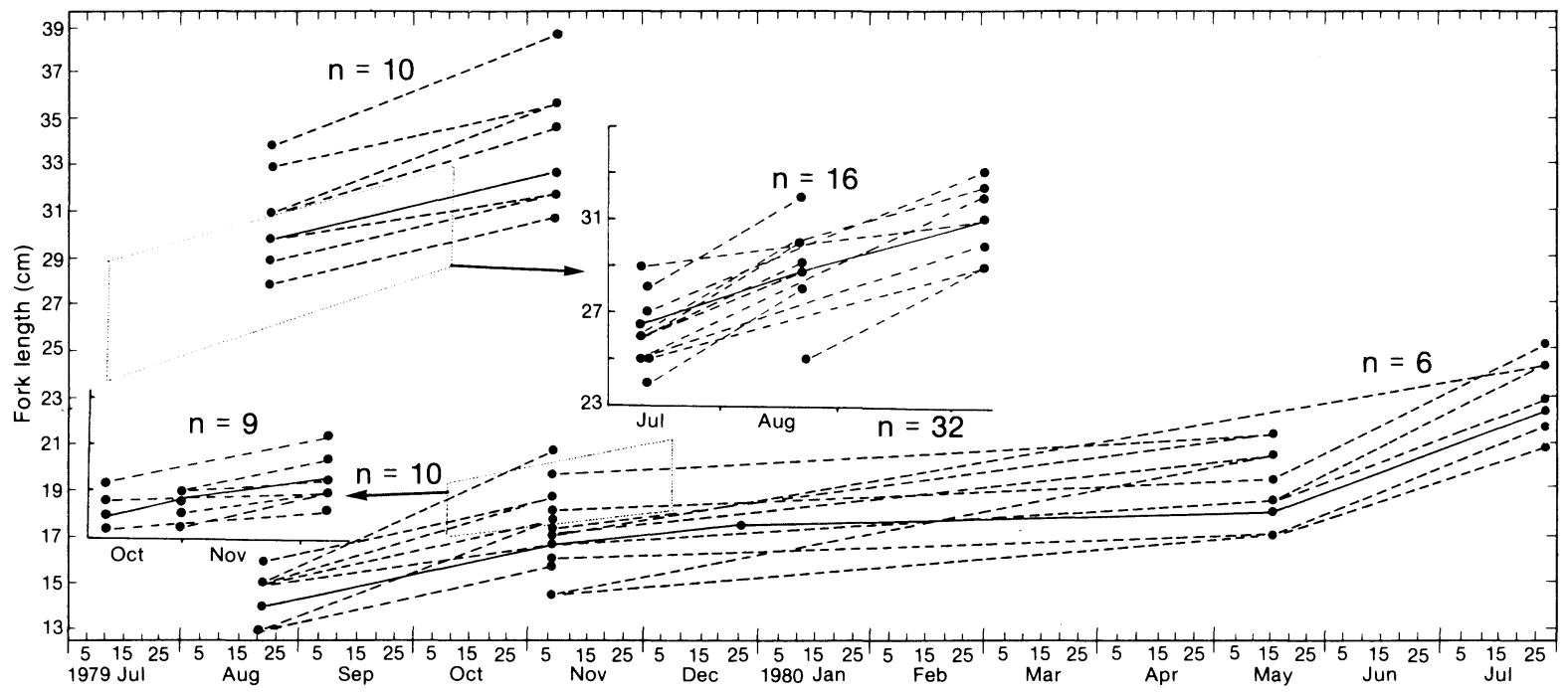

Fig. 5. Growth of tagged individual pollock from Halifax Harbour (1979 and 1980) and from Tiverton (1979). Fish from Tiverton are shown in the inserts $(n=9$ and $n=16)$ with their relative locations indicated by the dotted box. All other fish are from Halifax Harbour. Dashed lines can represent more than one fish. The solid lines represent the modes of the fish captured on that day.

than in linear form, the seasonal changes in the growth data reflect this curvilinear aspect.

It appears from Fig. 4 data, and from both direct observation of anglers and discussions with them, that pollock greater than $30 \mathrm{~cm}$ in length are rarely found in shallow inshore waters. Bigelow and Schroeder (1953) observed that in August pollock of $20-25 \mathrm{~cm}$ in length disappeared from the inshore area of the Gulf of Maine. Therefore, the median lengths of the cohort of larger fish in this study will be low compared to those of the overall population due to the offshore movement of larger individuals. Thus, the growth implied from analysis of the median lengths would be a minimum for juvenile inshore pollock.

Two factors affecting growth estimates from this study can not be quantified. The first is the decrease in growth expected resulting from the tagging operation and the tag itself, and the second is the increase expected from fish resulting from access to abundant food supplies (e.g. fish plant outfalls). A further contributing factor is that the density of fish in areas of plant outfalls were orders of magnitude greater than those observed elsewhere along the coast. The growth rate will vary because of these factors, but we assume the seasonal pattern of growth between sites will be similar.

\section{Overwinter survival after tagging}

Of the 150 fish caught in December 1979, 5 died before the January 1980 tagging. The length ranges of the remaining 102 tagged fish and 43 controls were 14-22 cm and 16-23 cm respectively, with the modal lengths being 17.5 and $18 \mathrm{~cm}$ respectively. Mortality of the tagged pollock was $16 \%$ during the first 3 months (January to March) while untagged controls had a $5 \%$ mortality; thus the tag induced mortality during the experiment in the first 3 months was about $11 \%$. During this period the 102 tagged fish appeared to lose weight (a visual impression), while the untagged fish did not, suggesting a tagging induced effect. The observed rate of mortality was relatively constant throughout the study period for both tagged and untagged fish.

During the inspection and change of net in late March, 19 of the tagged fish were found to have developed tag wounds. Eight of these fish with the most serious wounds died by the end of March. Despite these wounds, no fungal or other secondary infection was visually apparent on the fish, possibly due to the low winter water temperatures (surface temperatures $0^{\circ}$ to $-1^{\circ} \mathrm{C}$ ). Even dead fish appeared free of such external infection, although the tags on the fish (and the cage netting) supported a heavy growth of algae.

The fish may have been stressed by many factors such as handling and surface waters in which they were held. Pollock with freedom to move to an optimum winter habitat should experience a tagging mortality no greater than the $11 \%$ experienced by the aged fish, probably less. These results indicate meaningful returns can be expected even from winter tagging of juvenile pollock inshore prior to their recruitment to the commercially exploited offshore population.

This experiment was primarily designed to assess survival of tagged fish. Although growth in the cage would not be directly comparable to that in the wild, it does provide our only information on growth between January and March. The weighted mean $(n=83)$ absolute growth rate of tagged caged pollock was $0.12 \pm 0.24$ $\mathrm{cm}$ per month from January until March, including 14 fish which had zero growth. The value $G$ over this period was 0.01 . 


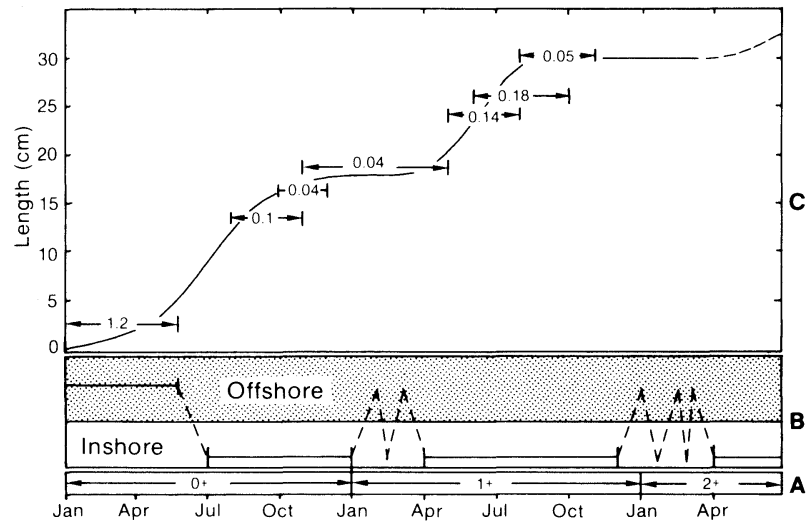

Fig. 6. Graphical summary of the life history of young pollock during their first 30 months of life: (A) age of juveniles; (B) offshoreinshore movements; (C) observed growth for the full period and monthly instantaneous growth for known portions of the period.

\section{Summary}

A graphic summary of the movements and growth of young pollock during their first 30 months of life is provided in Fig. 6. O'Boyle et al. (1984) examined data from ichthyoplankton surveys conducted in nearly every month of the year and found large numbers of pollock eggs and larvae on the Scotian Shelf from November to March. We assumed that spawning occurs at that time. The juveniles move inshore during their first summer and remain there for approximately 2 years. Data indicate that by the end of the first year of life (Fig. 4), the median length of pollock in the inshore areas of Atlantic Canada is in the order of $17 \mathrm{~cm}$ (annual $\mathrm{G}=4.1$ calculated from the weight equation) and $30 \mathrm{~cm}$ by the end of the second year (annual $G=1.8$ ). The growth of known age individuals (Fig. 5) suggest lengths at the end of the first and second years of 17 and $27.5 \mathrm{~cm}$ respectively.

\section{Acknowledgements}

Any operation of this magnitude requires a group effort and many members of the Marine Fish Division, Department of Fisheries and Oceans, Dartmouth, Nova Scotia, assisted in the tagging at various times. Bill Smith supervised the operations at Canso in 1978, 1979 and 1980. Diane Beanlands, Bev Charlton, Pat Simpson, Bernie Swan, and Gerry Young have all assisted in tagging juveniles at various times and places. Irma Thompson of the Marine Fish Division, St. Andrews
Biological Station, New Brunswick, handled the data coding, editing and payment of rewards. Bob O'Boyle and Steve Campana of BIO and Mike Chadwich of the Gulf Fisheries Center, Moncton, New Brunswick, all provided useful comments on the initial draft.

\section{Disclaimer}

The mention of brand names should not be construed as an endorsement by the Department of Fisheries and Oceans, Canada or the authors.

\section{References}

ANON. 1976. Report of standing committee on research and statistics. Part C. Pollock in Div. 4V, 4W, 4X and Subarea 5. ICNAF Redbook, 1976: p. 90.

ANON. 1984. Advice on the management of groundfish stocks in 1985. CAFSAC Ann. Rep., 1984, 7: 102-103.

BIGELOW, H. B., and W. C. SCHROEDER. 1953. Fishes of the Gulf of Maine. Fish. Bull., U.S., 53: 577 p.

CLUTTER, R. I., and M. ANRAKU. 1968. Avoidance of samplers. In: D. J. Tranter and J. H. Fraser (eds.) Monographs in Oceanographic Methodology II. Zooplankton sampling. UNESCO, Paris: 57-76.

COLTON, J. B., Jr., and R. R. BYRON. 1977. Gulf of MaineGeorges Bank Ichthyoplankton collected on ICNAF Larval Herry Surveys, September 1971-February 1975. NOAA Tech. Rep. NMFS (Spec. Sci. Rep. Fish), 717: 35 p.

COLTON, J. B., W. G. SMITH, A. W. KENDALL, P. L. BERRIEN, and M. P. FAHAY. 1979. Principal spawning areas and times of marine fishes, Cape Sable to Cape Hatteras. Fish. Bull., U.S., 76: 911-915.

FAHAY, M. P. 1983. Guide to the early stages of marine fishes occurring in the western North Atlantic Ocean, Cape Hatteras to the southern Scotian Shelf. J. Northw. Atl. Fish. Sci., 4: 180-181.

McGLADE, J., M. C. ANNAND, and D. BEANLANDS. MS 1984. Assessment of pollock (Pollachius virens) in Divisions 4VWX and SA 5. CAFSAC Res. Doc., No. 77, 33 p.

O'BOYLE, R. N., M. SINCLAIR, R. J. CONOVER, K. H. MANN, and A. C. KOHLER. 1984. Temporal and spatial distribution of ichthyoplankton communities of the Scotian Shelf in relation to biological, hydrological, and physiographic features. ICES Rapp. Proc.-Verb., 183: 27-40.

RICKER, W. E. 1975. Computation and interpretation of biological statistics of fish populations. Bull. Fish. Res. Board Can., 191: $382 \mathrm{p}$

SCOTT, J. S. 1980. Occurrence of pollock, Pollachius virens, and sand lance, Ammodytes sp., larvae in the Bay of Fundy. J. Northw. Atl. Fish. Sci., 1: 45-48.

STEELE, D. H. 1963. Pollock (Pollachius virens (L.)) in the Bay of Fundy. J. Fish. Res. Board Can., 20: 1267-1314. 
